\title{
Review of Alternative Residual \\ Contamination Guides for the 324 Building B-Cell Cleanout Project, Phase I
}

G. J. Vargo

J. S. Durham

L. W. Brackenbush

September 1995

Prepared for the U.S. Department of Energy under Contract DE-AC06-76RLO 1830

Pacific Northwest Laboratory

Operated for the U.S. Department of Energy

by Battelle Memorial Institute

\section{Battelle}




\section{DISCLAIMER}

Portions of this document may be illegible in electronic image products. Images are produced from the best available original document. 
Review of Alternative Residual Contamination Guides for the 324 Building B-Cell Cleanout Project, Phase 1

\author{
G. J. Vargo \\ J. S. Durham \\ L. W. Brackenbush
}

September 1995

Prepared for the U.S. Department of Energy under Contract DE-AC06-76RLO 1830

Pacific Northwest Laboratory Richland, Washington 99352 


\section{Summary}

This report provides a proposed residual contamination guide (RCG) for the 324 Building B-Cell Cleanout Project, Phase 1, at the Hanford Site. The RCG is expressed as a fraction of the amount of highly dispersible radioactive material that would result in offsite doses equal to the Pacific Northwest Laboratory radiological risk guidelines following the worst credible accident scenario for release of the holdup material. The proposed RCG is $10^{-1}$ to $10^{-2}$ of the PNL radiological risk guidelines.

As part of the development of the RCG, a number of factors were considered. These include the need to provide an appropriate level of flexibility for other activities within the 324 Building that could contribute to the facility's overall radiological risk, uncertainties inherent in safety analyses, and the possible contribution of other 300 Area facilities to overall radiological risk. Because of these factors and the nature of the cleanout project, the RCG is expressed as a range rather than a point value. This report also provides guidance on determining conformance to the RCG, including inspection and measurement techniques, quality assurance requirements, and consideration of uncertainty. 



\section{Contents}

Summary $\ldots \ldots \ldots \ldots \ldots \ldots \ldots \ldots \ldots \ldots \ldots \ldots \ldots \ldots \ldots \ldots \ldots$ iii

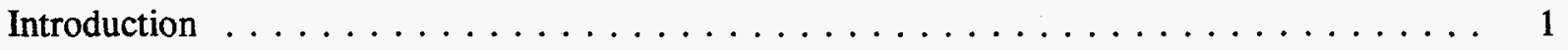

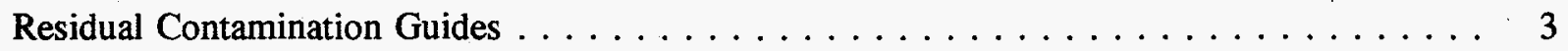

Recommended Residual Contamination Guideline for B-Cell Cleanout Project, Phase 1 . . . 7

Determining Conformance to the Residual Contamination Guide - Inspection

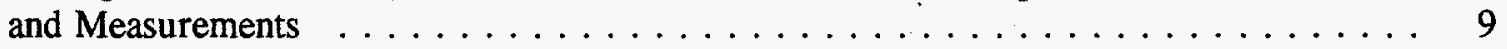

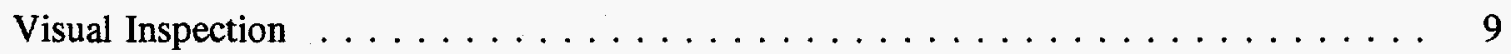

Ambient Dose Rate Measurements $\ldots \ldots \ldots \ldots \ldots \ldots \ldots \ldots$

Direct Sampling $\ldots \ldots \ldots \ldots \ldots \ldots \ldots \ldots \ldots \ldots \ldots \ldots \ldots \ldots \ldots$

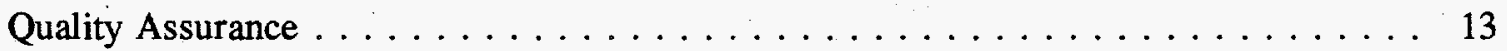

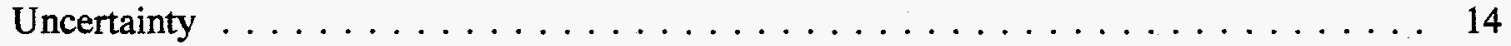

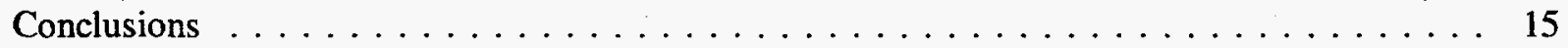

References $\ldots \ldots \ldots \ldots \ldots \ldots \ldots \ldots \ldots \ldots \ldots \ldots \ldots \ldots$

\section{Tables}

1 Pacific Northwest Laboratory Risk Guidelines . . . . . . . . . . . . . 2

2 Surface Activity Guides Requiring Management as a Contamination Area from PNL-MA-6 



\section{Introduction}

A major process equipment leak, involving approximately $510 \mathrm{~L}$ of liquid-fed ceramic melter feed occurred in the B-Cell of the 324 Building on the U.S. Department of Energy's (DOE's) Hanford Site, in October 1986. This leak resulted in the accumulation (holdup) of approximately $1.3 \mathrm{MCi}$ (48 PBq) of fission products, predominantly ${ }^{90} \mathrm{Sr}$ and ${ }^{137} \mathrm{Cs}$. Prior leaks and releases inside the cell are estimated to be $0.2 \mathrm{MCi}(7.4 \mathrm{PBq})$ for a total of 1.5 MCi (55.4 PBq). In June 1993, it was determined that the current authorization basis for the 324 Building did not analyze the risks resulting from the following two factors:

- the presence of dispersible radioactive material (dust and debris) in the B-Cell, and

- B-Cell operations to package and remove dispersible radioactive material

As a consequence, an Unreviewed Safety Question (USQ) was declared. The USQ Resolution Document, 324 Building Authorization Basis, Supplement for B-Cell Holdup Material and Cleanout Operations, ${ }^{(a)}$ which expands the current authorization basis to include the risks associated with the B-Cell holdup material and cleanout activities.

In mid-FY 1993, it was decided to focus the 324 and 325 Building Hot-Cell Restoration Program (initiated in mid-FY 1988) on the 324 Building B-Cell with a goal of adequately reducing the radiological health risk. The mission of the B-Cell Cleanout Project, Phase 1, is "to eliminate the unacceptable radiological hazard associated with the 324 Building B-Cell in a responsible manner." ${ }^{\text {(b) }}$ This means that at the conclusion of the project, the amount and form of radioactive material remaining in the 324 Building B-Cell is such that Pacific Northwest Laboratory (PNL) ${ }^{(c)}$ risk guidelines will not be exceeded for any credible accident involving the 324 Building. These risk guidelines are contained in PNL-MA-44, Safety Analysis ${ }^{(\mathrm{d})}$ and are summarized in Table 1, expressed as committed effective dose equivalent to a maximum exposed individual.

In September 1994, the manager of the 324 B-Cell Cleanout Project requested that the PNL Health Protection Department (HPD) evaluate and recommend residual contamination guides (RCGs) for the project. As part of this effort, the HPD was requested to review applicable rules, orders, standards, and guidance for the selection of suitable RCGs and propose possible methods for verifying that a given RCG level has been achieved.

\footnotetext{
(a) 324 Building Authorization Basis, Supplement for B-Cell Holdup Material and Cleanout Operations, Pacific Northwest Laboratory, Richland, Washington, December 22, 1994.

(b) B-Cell Cleanout Project, Phase 1, Project Management Plan, Pacific Northwest Laboratory, April 1994.

(c) The Pacific Northwest Laboratory is operated for the U.S. Department of Energy by Battelle Memorial Institute under Contract DE-AC06-76RLO 1830.

(d) Safety Analysis, PNL-MA-44, Pacific Northwest Laboratory, Richland, Washington, June 1993.
} 
Table 1. Pacific Northwest Laboratory Risk Guidelines

\begin{tabular}{|c|c|c|}
\hline $\begin{array}{c}\text { Event } \\
\text { Frequency }\end{array}$ & $\begin{array}{c}\text { Onsite Maximum Exposed } \\
\text { Individual, rems }\end{array}$ & $\begin{array}{c}\text { Offsite Maximum Exposed } \\
\text { Individual, rems }\end{array}$ \\
\hline $\begin{array}{c}\text { Anticipated } \\
\left(10^{\circ} \text { to } 10^{-2} / \mathrm{y}\right)\end{array}$ & 0.1 & 0.004 \\
\hline $\begin{array}{c}\text { Unlikely } \\
\left(10^{-2} \text { to } 10^{-4} / \mathrm{y}\right)\end{array}$ & 10 & 0.4 \\
\hline $\begin{array}{c}\text { Extremely Unlikely } \\
\left(10^{-4} \text { to } 10^{-6} / \mathrm{y}\right)\end{array}$ & 100 & 40 \\
\hline $\begin{array}{l}\text { Incredible } \\
\left(<10^{-6} / \mathrm{y}\right)\end{array}$ & \multicolumn{2}{|}{} \\
\hline
\end{tabular}

B-Cell also contains mixed wastes, ${ }^{(a)}$ and negotiations on the disposition of these wastes have been ongoing between the DOE, the Washington State Department of Ecology, the Environmental Protection Agency (EPA), and PNL. Pacific Northwest Laboratory is currently preparing a Resource Conservation and Recovery Act (RCRA) Closure Plan that addresses technical alternatives for waste disposition, assesses the feasibility of "clean closure," and integrates RCRA closure with on-going B-Cell cleanout activities. Completion of this plan is expected late in the third quarter of FY 1995. Recent detail on the mixed waste compliance status has been documented (Flores et al. 1995). The recommendations in this report will provide useful input to the RCRA Closure Plan. As the closure plan is being finalized, these recommendations will be reviewed and updated as necessary.

(a) Mixed waste (MW) contains both nonradioactive hazardous/dangerous waste, and radioactive source, special nuclear, or by-product material subject to the Atomic Energy Act. Mixed waste is regulated by the U.S. Environmental Protection Agency (EPA) under the RCRA regulations (40 CFR 260-270) and by the Washington State Department of Ecology under the state equivalent of the RCRA regulations, the Dangerous Waste Regulations (WAC 173-303), hereafter referred to as RCRA. Management of the radioactive characteristic of mixed waste, if classified by the DOE as source, special, or nuclear by-product material, is reserved to DOE. 


\section{Residual Contamination Guides}

A residual contamination guide (RCG) between $10^{-2}$ and $10^{-1}$ of the PNL radiological risk guideline is proposed. Such an RCG fulfills the project mission by adequately reducing the health risk and also provides a reasonable operating margin for other activities within the 324 Building. The use of a single inflexible RCG may not be appropriate because of uncertainty in the effectiveness of recovery and decontamination techniques. For example, because of the relatively high solubility of $\mathrm{CsNO}_{3}$ and $\mathrm{Sr}\left(\mathrm{NO}_{3}\right)_{2}$, the principal chemical forms of radioactive contamination from the melter feed process leak into B-Cell, an additional hot water flush of the floor following retrieval of debris could possibly reduce the remaining activity from $10^{-1}$ to $10^{-3}$ of the PNL radiological risk guideline in a single step. While such an action would go beyond the RCG for the project, the action might be reasonable, prudent, and justified in terms of a relatively small incremental cost and personnel dose. The B-Cell Cleanout Project, Phase 1, is not a decontamination and decommissioning project in the traditional sense. Rather, the purpose of this project is to adequately reduce the radiological health risk associated with the holdup material in B-Cell. While no specific RCGs are given in project documentation, Section 2.2.1 of the B-Cell Cleanout Project, Phase 1 Project Management Plan states that the "(p)roject cleanout criteria are assumed to be $<2000$ curies ${ }^{90} \mathrm{Sr}$ for highly mobile and $<40,000$ curies ${ }^{90} \mathrm{Sr}$ for mobile contamination."

The most recently approved PNL safety analysis document for the 324 Building includes a calculation of the amount of holdup material that would result in offsite doses equal to the PNL risk guidelines following the worst credible accident scenario for release of the holdup material, which is a seismic event without process upsets. Using the assumption that the ratio of ${ }^{137} \mathrm{Cs}$ to ${ }^{90} \mathrm{Sr}$ is $2: 1$ in the holdup material and that the sole contributor to offsite doses from the $300 \mathrm{Area}$ is the source term in B-Cell, an inventory of $14,000 \mathrm{Ci}(518 \mathrm{TBq})$ of ${ }^{90} \mathrm{Sr}$ and $28,000 \mathrm{Ci}(1.03 \mathrm{PBq})$ of ${ }^{137} \mathrm{Cs}$ would result in an offsite dose equal to the $0.4 \mathrm{rem}(4 \mathrm{mSv})$ PNL radiological risk guideline for the "Unlikely" event frequency category, which covers the case of a seismic event without process upsets, i.e., the worst credible accident scenario.

Because of the need to ensure that the facility as a whole is maintained under these limits, because of uncertainties inherent in accident analyses and the accompanying dose calculations, and because other facilities in the 300 Area could contribute to the offsite dose from a seismic event; it is imperative that a margin of safety below the PNL radiological risk guideline be established through definition of the endpoint of cleanout. Additionally, use of the maximum values as the endpoint for cleanout is undesirable from a programmatic viewpoint because this does not allow for operational flexibility within the 324 Building. It is recognized that the calculated amount of holdup material that would result in offsite doses equal to the PNL radiological risk guidelines may change from the amounts in the December 22, 1994, safety analysis document. Changes could result from DOE review of this document, the preparation and review of the 324 Building Safety Analysis Review (SAR) documents, and changes to PNL risk guidelines. 
A number of guidance documents were reviewed in an effort to identify suitable RCGs for the B-Cell Cleanout Project, Phase 1, including the DOE General Design Criteria contained in DOE Order 6430.1A, the 5400-series nuclear safety orders, 10 CFR 835 (Occupational Radiation Protection), and the DOE Radiological Control Manual (DOE/EH-0256T, Rev. 1). With the exception of DOE Order 5480.11, Radiation Protection for Occupational Workers, none of the Orders reviewed provided specific guidance on acceptable surface contamination levels that could be used in the development of an RCG for the project. The guidance in DOE 5480.11 is essentially the same as that contained in 10 CFR 835 and the DOE Radiological Control Manual.

These surface activity guides, shown in Table 2, are intended for the unrestricted release of materials from radiologically controlled areas and are also used as the threshold for determining when an area should be posted and controlled as a Contamination Area, per PNL-MA-6, the PNL Radiological Control Manual. (a) $^{\text {an }}$

Table 2. Surface Activity Guides Requiring Management as a Contamination Area from PNL-MA-6

\begin{tabular}{|c|c|c|}
\hline Nuclide & $\begin{array}{l}\text { Removable } \\
\text { Contamination, } \\
\text { dis } / \min / 100 \mathrm{~cm}^{2}\end{array}$ & $\begin{array}{c}\text { Total Contamination } \\
\text { (fixed + removable), } \\
\text { dis } / \mathrm{min} / 100 \mathrm{~cm}^{2}\end{array}$ \\
\hline $\begin{array}{l}\mathrm{U} \text {-nat, }{ }^{235} \mathrm{U},{ }^{238} \mathrm{U} \text {, and } \\
\text { associated decay products }\end{array}$ & 1000 & 5000 \\
\hline $\begin{array}{c}\text { Transuranics } \\
{ }^{226} \mathrm{Ra},{ }^{228} \mathrm{Ra},{ }^{230} \mathrm{Th},{ }^{228} \mathrm{Th},{ }^{231} \mathrm{~Pa}, \\
{ }^{227} \mathrm{Ac},{ }^{125} \mathrm{I},{ }^{129} \mathrm{I}\end{array}$ & 20 & 500 \\
\hline $\begin{array}{c}\text { Th-nat, }{ }^{232} \mathrm{Th},{ }^{90} \mathrm{Sr},{ }^{223} \mathrm{Ra},{ }^{224} \mathrm{Ra}, \\
{ }^{126} \mathrm{I},{ }^{131} \mathrm{I},{ }^{133} \mathrm{I}\end{array}$ & 200 & 1000 \\
\hline $\begin{array}{l}\text { Beta-gamma emitters } \\
\text { (nuclides with decay modes } \\
\text { other than alpha emission } \\
\text { or spontaneous fission), except } \\
{ }^{90} \mathrm{Sr} \text { and others noted above }\end{array}$ & 1000 & 5000 \\
\hline
\end{tabular}

The volume of the B-Cell is $474 \mathrm{~m}^{3}$ and its surface area is $368 \mathrm{~m}^{2}$. This represents $32 \%$ of the hot cell volume and $26 \%$ of the hot cell surface area within the 324 Building. If the surface contamination is assumed to be mixed fission products $\left({ }^{137} \mathrm{Cs}\right.$ and $\left.{ }^{90} \mathrm{Sr} /{ }^{90} \mathrm{Y}\right)$ and it was desired to clean

(a) Radiological Control Manual, PNL-MA-6, Pacific Northwest Laboratory, Richland, Washington. 
B-Cell to meet the guideline value for residual contamination for release of material $\left(5,000 \mathrm{dis} / \mathrm{min} / 100 \mathrm{~cm}^{2}\right)$, then the residual contamination in the B-Cell would be approximately $42 \mu \mathrm{Ci}$ $(1.6 \mathrm{MBq}){ }^{137} \mathrm{Cs}, 21 \mu \mathrm{Ci}(0.8 \mathrm{MBq}){ }^{90} \mathrm{Sr}$, and $21 \mu \mathrm{Ci}(0.8 \mathrm{MBq}){ }^{90} \mathrm{Y}$. This is between $10^{-11}$ and $10^{-10}$ of the permitted residual contamination based upon PNL's radiological risk guidelines. Although adopting these values would clearly eliminate any safety issues, the goal of the B-Cell cleanout is to reduce the offsite risk from an unlikely accident, not release of the cell from radiological control. Cleaning B-Cell to meet the guideline values is impractical and not cost-effective.

An RCG based on allowing manned entry into the hot cell would result in a significantly larger inventory than one based on the surface activity guides that require posting and control as a Contamination Area. For example, the dose rate from an infinite plane source of ${ }^{137} \mathrm{Cs}$ at a concentration of $1 \mu \mathrm{Ci} / \mathrm{cm}^{2}\left(37 \mathrm{kBq} / \mathrm{cm}^{2}\right)$ is approximately $140 \mathrm{mrem} / \mathrm{h}(1.4 \mathrm{mSv} / \mathrm{h})$ at a distance of $100 \mathrm{~cm}$ (roughly waist level) from the source. If this value were scaled up, the RCG would result in an inventory of approximately $2 \mathrm{Ci}(74 \mathrm{GBq}){ }^{137} \mathrm{Cs}, 1 \mathrm{Ci}(37 \mathrm{GBq}){ }^{90} \mathrm{Sr}$, and $1 \mathrm{Ci}(37 \mathrm{GBq}){ }^{90} \mathrm{Y}$. These values are between $10^{-5}$ and $10^{-4}$ of the permitted residual contamination based upon PNL's radiological risk guidelines. While such an RCG might be highly desirable because of other considerations (e.g., future projects in the B-Cell), it goes far beyond the present project mission and is not cost-effective for the B-Cell Cleanout Project, Phase 1.

Considerable experience has been gained in periodically decontaminating the airlock and in the decontamination of C-Cell in FY 1989. Both decontamination activities were completed using high-pressure water spray and detergent foam soak, followed by high-pressure water spray. The ultrahigh-pressure water decontamination system being installed in the airlock for evaluation should offer further improvement. If it works well in the airlock, installation in B-Cell will be evaluated.

While the selection of an RCG for Phase 1 of the project is driven only by the need to reduce the health risk associated with holdup material in a timely manner, the ultimate selection of an RCG should also consider operational flexibility for other activities within the 324 Building facility as well as candidate future uses for the B-Cell. Such an RCG may be lower than that needed to adequately reduce the health risk associated with holdup material in B-Cell. As part of this study, five potential future projects related to the Hanford cleanup were considered:

- tank waste remediation demonstration

- high-level waste vitrification process improvement demonstration

- smelting of contaminated/activated metals for volume reduction and recycling

- mixed waste treatment and disposal technology demonstration

- decontamination and decommissioning technology demonstrations for 200-Area facilities. 
These activities could involve processing quantities of radioactive material similar to those encountered in the past. An RCG of $10^{-1}$ to $10^{-2}$ of the PNL radiological risk guidelines would not impose significant difficulties on likely future projects. 


\section{Recommended Residual Contamination Guideline for B-Cell Cleanout Project, Phase 1}

Based on the material presented and discussed in the prior section, it is recommended that the RCG for the B-Cell Cleanout Project, Phase 1, be set at a level between $10^{-1}$ and $10^{-2}$ of the cell inventory allowable at the PNL radiological risk guidelines. 


\section{Determining Conformance to the Residual Contamination Guideline - Inspection and Measurements}

Determining conformance to the RCG established for the B-Cell Cleanout Project, Phase 1, is the major indicator of project success. The planned approach involves a multistage process that includes visual inspection followed by ambient dose rate measurements performed inside the cell followed by direct measurements using smear samples and radiochemical analysis. The validity of the direct sampling (i.e., smear samples) depends, in part, on the presence of a visually clean surface.

\section{Visual Inspection}

Because of the relatively large volume of the process equipment leak (approximately $510 \mathrm{~L}$ ) and the volume of loose dust and debris present in the bottom of B-Cell, it is possible to use visual examination as a first approximation of the remaining holdup activity. The process equipment leak covered an area of approximately $25 \mathrm{~m}^{2}$ to a depth of approximately $2 \mathrm{~cm}$. Existing dust and debris in the area of the leak ranged from 7 to $30 \mathrm{~cm}$ in depth, and it is assumed that the final depth of the highly mobile material (i.e., the dried dust and nitrate solution) is $2 \mathrm{~cm}$. Under these conditions, the volume of the highly mobile holdup material is approximately $0.5 \mathrm{~m}^{3}$, a volume readily apparent to the unaided eye.

Assuming that the dust and debris are uniformly contaminated as a result of prolonged soaking, the specific activity of the highly mobile holdup material is approximately $3 \mathrm{Ci} / \mathrm{mL}(111 \mathrm{GBq} / \mathrm{mL})$. Using the upper-bound RCG value of $10^{-1}$ recommended above, the volume of highly mobile holdup material remaining in $\mathrm{B}-\mathrm{Cell}$ would be on the order of $1 \mathrm{~L}$, a volume that could be observed using commercially available high-resolution closed-circuit television (CCTV) equipment. The acceptance criteria for this step should be a surface that is free of visible dust and debris.

The primary advantage of using visual inspection as a screening step in determining conformance to the RCG values is that it eliminates the need for direct radiation surveys and sampling until there is reasonable assurance that cleanout efforts have progressed to a point approaching the RCGs.

Conversely, if loose debris is observed in B-Cell, it can be concluded that further cleanout efforts are required.

The advantages and disadvantages of taking smear samples in B-Cell at the present time, and continuing through completion of cell cleanout have been evaluated. The benefit would be more information on the nature of surface contamination in the cell versus time and cleanout progress, in terms of radionuclides and their chemical form. This information could be useful in determining techniques to use for final cleaning in Phase 1. Conversely, the work would consume project funds and would have little direct contribution to approaches used to resolve the B-Cell safety problem. Indications are that the bulk of the contamination in the cell is in a very water-soluble form, and that once the floor debris is collected and the floor is vacuumed, final cleaning in Phase 1 should be relatively straightforward. 
Based on the evaluation of potential advantages and disadvantages, and the ability to make bounding estimates of the holdup activity using visual examination, taking smear samples in B-Cell does not appear to be warranted at this time. Given the anticipated chemical and physical forms of the contaminants in B-Cell, the recommended RCG levels should be easily met. It is likely that the ambient dose rates in the cell after cleanout will be an order of magnitude lower than the dose rates associated with the RCG values.

\section{Ambient Dose Rate Measurements}

Ambient dose rate measurements will provide an indication that the contamination level in B-Cell is close to the RCG once the cell has been cleaned and large nondispersible sources such as spent nuclear fuel assemblies and control rods have been removed. If such sources are left in the cell, the measurement process becomes more complicated. In this case, the use of ambient dose rate measurements might be inappropriate, requiring greater reliance on direct sampling of the cell interior surfaces described below.

For purposes of comparison, dose rates within the B-Cell were evaluated for the case where the inventory of ${ }^{137} \mathrm{Cs}$ and ${ }^{90} \mathrm{Sr}$ results in meeting the 0.4-rem PNL radiological risk guideline. The computer code WISE (Reece et al. 1989) was used to calculate the dose rate in the center of B-Cell for three residual contamination scenarios using this inventory. The WISE code has been peer-reviewed and validated and is in common use at commercial nuclear power stations throughout the United States. WISE uses the point-kernel method to calculate both beta and gamma doses from a wide range of geometrical shapes. Because WISE uses a point-kernel method, it does not include the effect of backscatter. In addition, it can only estimate the quantity of bremsstrahlung radiation generated by the residual contamination. Despite these simplifying assumptions, WISE is useful for determining the dose rates generated by the residual contamination level within $20 \%$. If more accuracy is needed for final verification, a Monte Carlo code could be used.

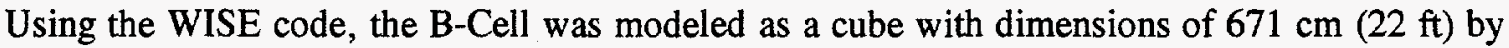

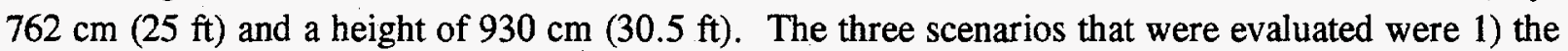
contamination is uniformly distributed over all surfaces of the cell, 2) the contamination is uniformly distributed over the walls and floor of the cell, and 3) the contamination is uniformly distributed over the floor of the cell. For scenario 1 , the dose rate at the center of the cell was estimated to be $460 \mathrm{rem} / \mathrm{h}(4.6 \mathrm{mSv} / \mathrm{h})$; and for scenario $2,480 \mathrm{rem} / \mathrm{h}(4.8 \mathrm{mSv} / \mathrm{h})$; and for scenario $3,720 \mathrm{rem} / \mathrm{h}$ $(7.2 \mathrm{mSv} / \mathrm{h})$. These dose rates are sufficiently high that verification that the RCG has been met could be accomplished by measuring the ambient dose rates in B-Cell following cleanout.

A system of verification that places primary emphasis on ambient dose rate measurements should be adopted. Ambient dose rates in the cell would be on the order of $10^{1}$ to $10^{\circ} \mathrm{rem} / \mathrm{h}\left(10^{2}\right.$ to $10^{1} \mathrm{mSv} / \mathrm{h}$ ) for an RCG of $10^{-1}$ and $10^{-2}$ of the risk guideline, respectively. The ambient dose rate provides an indication of the amount of ${ }^{137} \mathrm{Cs}$ remaining in the cell: All ambient dose rate measurement techniques are most applicable in showing conformance to the RCG when the nondispersible radioactive source term has been removed from B-Cell. Examples of this nondispersible source term 
include retired equipment, nuclear fuel and associated non-fuel-bearing irradiated hardware, glass canisters, and packaged radioactive material. It is planned to measure dose rates in the center of the cell using a dose rate probe such as an ionization chamber probe. By performing measurements with a shielded and collimated dose rate probe such as an ionization chamber, an indication of the relative amounts of ${ }^{137} \mathrm{Cs}$ on the walls, ceiling, and floor will be provided. The measured dose rate information will provide input data to the WISE computer code or to a Monte Carlo computer code, and the results of the calculations will indicate if the RCG has been met.

The use of ambient dose rate measurements as the primary indicator of success will also reduce overall costs by requiring fewer direct samples to be taken for detailed radiochemical analysis. The cost of radiochemical analysis is estimated at $\$ 2,000$ per sample.

In addition to measurements with an ionization chamber probe described above, a number of supplementary techniques may be used. One method that has been used to measure ambient dose rates is to position strings of thermoluminescent dosimeters (TLDs) or other passive dosimeters inside a plastic tube placed at strategic locations inside B-Cell for a known period of time. This technique is widely used to characterize complex radiation fields such as those encountered in high radiation areas in nuclear power plants (e.g., steam generators) as well as in radiation therapy where small TLDs are placed in anatomic models. If the walls of the plastic tube are thick enough to stop the beta radiation emitted by ${ }^{90} \mathrm{Y}$, the individual TLD results can be used as pixels to generate a "map" of the gamma radiation intensities inside the hot cell. Since the gamma radiation is believed to emanate primarily from ${ }^{137} \mathrm{Cs}$, the TLDs will provide an indication of the amount of ${ }^{137} \mathrm{Cs}$ remaining in the cell. In addition, a new dosimetry technique, cooled optically stimulated luminescence (COSL), which has been developed by PNL (Miller et al. 1988), allows accurate determination of radiation doses over ranges extending from $10^{-3}$ to $10^{7}$ rads $\left(10^{-5}\right.$ to $\left.10^{5} \mathrm{~Gy}\right)$. The COSL technique has the additional advantages of low fading (minimizing erroneous results) and a low processing cost.

Other ambient dose rate measurements have been performed in fields as high as $10^{3}$ to $10^{5} \mathrm{rads} / \mathrm{h}$ $\left(10^{1}\right.$ to $\left.10^{3} \mathrm{~Gy} / \mathrm{h}\right)$ using special small detectors. For example, dose rates and radionuclide inventories have been measured inside the tubes in steam generators removed from nuclear power plants. Special small cadmium telluride or mercuric iodide detectors have been used to measure gamma ray energy spectra to determine the inventory of gamma emitters as a function of position. These detectors are typically $\$ 5,000$ to $\$ 20,000$ for a complete spectrometry system. An existing gamma spectrometry system may be available at PNL for these type of measurements.

\section{Direct Sampling}

The amount of ${ }^{90} \mathrm{Sr}$ in the cell can only be accurately determined by performing direct sampling using smears. Once the ambient B-Cell dose rate is significantly below the predicted dose rates for an inventory that would result in a calculated offsite dose equal to the PNL radiological risk guidelines, determination of the fraction of ${ }^{90} \mathrm{Sr}$ and ${ }^{137} \mathrm{Cs}$ (and other radionuclides) will be made by performing direct sampling. Radiochemical analysis of the smears will provide information on the fractions of beta emitters, gamma emitters, uranium, and transuranics. It is noted that in preparing the RCRA Closure 
Plan for B-Cell, consideration will also be given to analyzing these smear samples for RCRA materials. Staff at the 324 Building have developed an apparatus for the collection of smear samples from the surfaces of the B-Cell interior that ensures consistent sampling. This will be useful in obtaining data from smooth surfaces once the equipment, waste, and loose, highly dispersible debris have been removed from the cell. It is planned to gain experience with this apparatus in other 324 Building cells or the radiochemical engineering cell airlock that services B-Cell.

Calculations of the B-Cell inventory that would give a maximum offsite dose of $0.4 \mathrm{mrem}$, which is the basis for the RCG limit, are based on the assumption that the ratio of ${ }^{137} \mathrm{Cs}$ to ${ }^{90} \mathrm{Sr}$ in $\mathrm{B}$-Cell after cleanout is $2: 1$. After analysis of the smear samples, the ratio could be shown to be different than assumed because of the difference in the initial inventory and behavior of the two radionuclides during cleanout operations. If the ratio is higher, the gross dose rate measurement would correspond to a potential offsite dose that is lower than that on which the RCG is based. If the ratio is lower, however, the potential offsite dose should be recalculated based on the direct measurements and the RCG should be revised. If water is used for decontaminating B-Cell, it is likely that the ratio would decrease.

The RCG is a dose-based quantity. Because of varying chemical and radiological characteristics, different radionuclides produce widely varying committed effective dose equivalents per unit activity. An example of this is shown in Table E.3 of the January 1992 draft Safety Analysis Report. ${ }^{(a)}$ It is, therefore, necessary to accurately determine the relative quantities of each radionuclide prior to making a determination that the RCG for Phase 1 of the B-Cell Cleanout Project has been achieved. For example, it is possible that once the melter feed spill has been removed from B-Cell, other radionuclides present in the cell as a result of other past activities (e.g., destructive examination of irradiated fuel assemblies) could be the dominant contributors to radiological risk. The assumption of a 2:1 ratio of ${ }^{137} \mathrm{Cs}$ to ${ }^{90} \mathrm{Sr}$ is useful for project planning and reasonable as a first approximation that cleanout efforts have been successful. However, determining actual conformance to the RCG will require a more accurate quantification of all the radionuclides present.

The relative contribution from $\mathrm{Cs}, \mathrm{Sr}$, and other radionuclides to the contamination in $\mathrm{B}-\mathrm{Cell}$ can be determined using direct measurements with smear samples. Because of the cost associated with analysis of the smears and the difficulties associated with handing material that could be significantly contaminated, the number of samples should be minimized. In order to provide a conservative estimate of the residual contamination in the cell, the minimum measured ratio of ${ }^{137} \mathrm{Cs}$ to ${ }^{90} \mathrm{Sr}$ in B-Cell after cleanout will be used to determine if the RCG has been met. A statistical tool known as a one-sided tolerance interval (Wadsworth 1990) can be used to gain a large amount of information with a minimum number of measurements.

A one-sided tolerance interval is a tool often used in statistical quality control in manufacturing. If 22 measurements are made, the one-sided tolerance interval allows the following statement to be made: with $67 \%$ confidence, at least $95 \%$ of the total population will be higher than the lowest

(a) Pacific Northwest Laboratory (PNL). 1992. Draft Safety Analysis Report for 324 Building Waste Technology Engineering Laboratory. PNL-7989, Richland, Washington. 
measurement. If a one-sided tolerance interval is applied to the direct measurements in the B-Cell, a total of 22 randomly distributed samples would be made in the cell. If these samples are analyzed and the ratio of ${ }^{137} \mathrm{Cs}$ to ${ }^{90} \mathrm{Sr}$ is determined for each sample, then it can be stated with $67 \%$ confidence that $95 \%$ of the entire cell surface contains a ratio of ${ }^{137} \mathrm{Cs}$ to ${ }^{90} \mathrm{Sr}$ that is higher than the lowest measured ratio. Thus, these measurements can be used to accurately determine a conservative ratio of ${ }^{137} \mathrm{Cs}$ to ${ }^{90} \mathrm{Sr}$ with a minimum number of measurements. If a higher confidence level is desired, the number of measurements must be increased. To achieve $90 \%$ confidence, a total of 45 measurements are required, while 59 measurements will raise the confidence interval to $95 \%$. Coupling the sample measurements with the dose rate measurements will provide confirmation that the residual contamination levels have been achieved.

Using more traditional statistical methods such as assuming a normal distribution of material and determining an average ratio of ${ }^{137} \mathrm{Cs}$ to ${ }^{90} \mathrm{Sr}$ would not provide a conservative indication that the RCG has been met. In addition, a normal distribution typically requires more than 22 measurements. The one-sided tolerance interval is the most efficient tool for determining the minimum ratio of ${ }^{137} \mathrm{Cs}$ to ${ }^{90} \mathrm{Sr}$. The one-sided tolerance interval has been previously used as the basis for a technique for performing contamination surveys for release of material (Durham et al. 1994).

\section{Quality Assurance}

Quality assurance is an important part of the measurement process. Since the RCG will be used to determine the endpoint for Phase 1 of the cleanout project, it is planned that the same level of rigor and formality be applied to these measurements as would be applied to any compliance test or measurement. Because this project is not a formal decontamination and decommissioning project, it is not necessary to obtain independent confirmatory measurements usually associated with projects where the goal is to release the facility from radiological control. Measurements should, however, include a statement of uncertainty to permit proper evaluation.

A review of DOE Order 5480.19, Conduct of Operations Requirements for DOE Facilities, indicates that measurements to determine conformance to the project RCG should be performed according to written procedures developed in accordance with the guidelines of Chapter XVI, Operations Procedures. Pacific Northwest Laboratory plans to develop the necessary procedures one year prior to the procedure need date.

Equipment for both direct assay and ambient dose rate measurements will be calibrated using standards traceable to the National Institute for Standards and Technology (NIST) or equivalent competent authority. Pacific Northwest Laboratory maintains the only NIST-accredited Secondary Laboratory (the Primary Laboratory being NIST itself) in the DOE complex for radiological calibrations. Measurements similar to those performed for radioactive waste characterization meet these requirements and are consistent with the requirements of DOE Order 5700.6C, Quality Assurance. 


\section{Uncertainty}

The method for approaching B-Cell Cleanout Project, Phase 1, outlined in this paper has a number of uncertainties. The uncertainties involved with the measurements that will be performed to assess the residual radioactive material inventory in B-Cell following cleanout will range from $1 \%$ to $5 \%$ for each measurement. Uncertainties in the calculated dose rates in the cell for a given radionuclide inventory are expected to be $20 \%$. The largest uncertainty is associated with the ratio of ${ }^{137} \mathrm{Cs}$ to ${ }^{90} \mathrm{Sr}$ in the cell after final cleaning. An approach to estimate this ratio in the final cleanout for Phase 1 is discussed in this paper.

Uncertainty exists in the present B-Cell radioactive material inventory. Based on process knowledge of the materials introduced into the cell and knowledge of material spilled to the cell floor, the ratio of ${ }^{137} \mathrm{Cs}$ to ${ }^{90} \mathrm{Sr}$ has been estimated at $2: 1$. As potentially dispersible contamination from the cell floor is collected, it will be screened to remove metallic debris, placed in an engineered in-cell storage container, and sampled. The samples will be analyzed, and the contents of the container designated as either mixed waste or as special case waste. The results of sample analysis will also give information on the ratio of ${ }^{137} \mathrm{Cs}$ to ${ }^{90} \mathrm{Sr}$. It is expected that the relative amounts of ${ }^{137} \mathrm{Cs}$ and ${ }^{90} \mathrm{Sr}$ remaining on the cell floor and walls will vary as cleanout activities progress. 


\section{Conclusions}

The conceptual basis for an RCG for the B-Cell Cleanout Project, Phase 1, inferred in the Project Management Plan and other correspondence appears to be sound. An RCG between $10^{-1}$ and $10^{-2}$ of the PNL radiological risk guidelines is reasonable, achievable, and provides operational flexibility for other hot cell operations within the 324 Building.

Measurements used to verify that the RCG has been met should combine measurements of the ambient dose rate in B-Cell and analysis of direct sampling measurements using smears. The ambient dose rate measurements will provide a measure of the amount of ${ }^{137} \mathrm{Cs}$ in the cell, while the direct measurements will provide a measurement of the residual ${ }^{90} \mathrm{Sr}$ in the cell. In addition, the direct measurements will indicate the presence and quantity of other radionuclides present in the cell. Using a collimated probe for the ambient dose rate measurements will allow an estimation of the relative activity that is on the ceiling, walls, and floor of the cell. Estimates of these relative contributions will be verified by the direct measurements.

The statistically based sampling method discussed in this paper should be used for the direct measurements. This approach will provide a cost-effective method for verifying conformance to the project RCG and can provide a large quantity of data without the need for handling large numbers of samples obtained from B-Cell. Direct measurements should not be performed until Phase 1 of the cleanout has been nearly completed and should only be used to verify that the goals of Phase 1 cleanout have been met. 



\section{References}

10 CFR 835. 1993. U.S. Department of Energy, "Radiation Protection for Occupational Workers." U.S. Code of Federal Regulations.

40 CFR 260-270. 1994. U.S. Environmental Protection Agency, "Protection of Environment." U.S. Code of Federal Regulations.

Durham, J. S., D. J. Gardner, and M. L. Johnson. 1994. Contamination Surveys for Release of Material. PNL-9789, Pacific Northwest Laboratory, Richland, Washington.

Flores, E. A., J. T. Fulton, S. W: Gajewski, J. H. Jarrett, M. H. Schlender, W. A. Ross, and P. J. Weaver. 1995. 324 Radiochemical Engineering Cells and High-Level Vault Tanks Mixed Waste Compliance Status White Paper. PNL-10370, Pacific Northwest Laboratory, Richland, Washington.

Miller, S. D., G. W. R. Endres, J. C. McDonald, and K. L. Swinth. 1988. "Cooled Optically Stimulated Luminescence in $\mathrm{CaF}_{2}: \mathrm{Mn}$." Radiation Protection Dosimetry 5(3):201-205.

Pacific Northwest Laboratory (PNL). 1992. Safety Analysis Report for 324 Building Waste Technology Engineering Laboratory. Pacific Northwest Laboratory, Richland, Washington.

Resource Conservation and Recovery Act (RCRA) of 1976. 42 USC 6901 et seq., as amended.

Reece, W. D., S. D. Miller, and L. A. Sigalla. 1989. Development of the WISE and SIMPLE Codes for Estimating Radioactive Waste Inventory and Shielding. NP-6226-CCML, Electric Power Research Institute, Palo Alto, California.

U.S. Department of Energy (DOE). 1988. Radiation Protection for Occupational Workers. DOE 5480.11, Washington, D.C.

U.S. Department of Energy (DOE). 1989. General Design Criteria. DOE 6430.1A, Washington, D.C.

U.S. Department of Energy (DOE). 1990. Conduct of Operations Requirements for DOE Facilities. DOE 5480.19, Washington, D.C.

U.S. Department of Energy (DOE). 1991. Quality Assurance. DOE 5700.6C, Washington, D.C.

U.S. Department of Energy (DOE). 1994. Radiological Control Manual. DOE/EH-0256T, Washington, D.C. 
Wadsworth, H. M., ed. 1990. Handbook of Statistical Methods for Engineers and Scientists. McGraw Hill, New York.

Washington Administrative Code (WAC). 1984. "Dangerous Waste Regulations." WAC-173-303, Olympia, Washington. 


\section{Distribution}

No. of

Copies

ONSITE

7 DOE Richland Operations Office

D. L. Clark

M. W. Jackson

D. C. Langstaff

D. L. Rice

C. R. Richins

D. E. Trader

M. C. Vargas

2 MacTech

D. Thornton

G. R. Yesberger

42 Pacific Northwest Laboratory

W. J. Apley

W. J. Bjorklund
A5-55

A5-55

K8-50

A5-55

K8-50

K8-50

K8-50

L6-34

A4-35

P8-30

P7-79
No. of

Copies

L. W. Brackenbush

K3-70

J. S. Durham

K3-55

J. T. Fulton

P8-34

R. L. Gruel

P8-30

K. R. Hoopingarner P7-35

D. R. Jackson P7-33

J. H. Jarrett

D. O. Jenkins

Y. B. Katayama

B. W. Killand

D. E. Knowlton

D. E. Lucas

M. H. Schendler

H. W. Slater

K. L. Soldat

J. E. Surma

R. E. Thornhill

G. J. Vargo (10)

P. J. Weaver

Information Release (7)

Technical Report Files (5) 